\title{
High oxygen ion conduction in sintered oxides of the $\mathrm{Bi}_{2} \mathrm{O}_{3}-\mathrm{Er}_{2} \mathrm{O}_{3}$ system
}

\author{
M. J. VERKERK, K. KEIZER, A. J. BURGGRAAF \\ Twente University of Technology, Department of Inorganic Materials Science, PO Box 217, \\ 7500 AE Enschede, The Netherlands
}

Received 22 February 1979

The phase diagram of the $\mathrm{Bi}_{2} \mathrm{O}_{3}-\mathrm{Er}_{2} \mathrm{O}_{3}$ system was investigated. A monophasic $\mathrm{f} c \mathrm{c}$ structure was stabilized for samples containing $17.5-45.5 \mathrm{~mol} \% \mathrm{Er}_{2} \mathrm{O}_{3}$. Above and below this concentration range polyphasic regions appear. The $\mathrm{fcc}$ phase showed high oxygen ion conduction. The ionic transference number is equal to one for specimens containing $30 \mathrm{~mol} \% \mathrm{Er}_{2} \mathrm{O}_{3}$ or less, while an electronic component is introduced at low temperatures for specimens containing $40-60 \mathrm{~mol} \% \mathrm{Er}_{2} \mathrm{O}_{3}$. Between $673 \mathrm{~K}$ and $873 \mathrm{~K}$ a maximum in the conductivity was found at $20 \mathrm{~mol} \% \mathrm{Er}_{2} \mathrm{O}_{3} \cdot\left(\mathrm{Bi}_{2} \mathrm{O}_{3}\right)_{0.80}\left(\mathrm{Er}_{2} \mathrm{O}_{3}\right)_{0.20}$ is found to be the best oxygen ion conductor so far known. The conductivity at $773 \mathrm{~K}$ and $973 \mathrm{~K}$ is $2.3 \Omega^{-1} \mathrm{~m}^{-1}$ and $37 \Omega^{-1} \mathrm{~m}^{-1}$ respectively. These values are $2-3$ times higher than the best oxygen ion conductor reported for substituted $\mathrm{Bi}_{2} \mathrm{O}_{3}$ systems and 50-100 times higher than those of stabilized zirconia $\left(\mathrm{ZrO}_{2}\right)_{0.915}\left(\mathrm{Y}_{2} \mathrm{O}_{3}\right)_{0.085}$ at corresponding temperatures.

\section{Introduction}

In the search for new inorganic compounds which exhibit predominantly oxygen ion conduction within a broad temperature range at lower temperatures, $\mathrm{Bi}_{2} \mathrm{O}_{3}$ was found to be a promising material. In the $\delta$-phase (face centred cubic, or $\mathrm{fcc}$ ), which exists between the transition point at about $1003 \mathrm{~K}$ up to the melting point at $1097 \mathrm{~K}$ $[1-5]$, the electrical conductivity is about $100 \Omega^{-1} \mathrm{~m}^{-1}[4,6]$. In the cooling direction this highly conductive phase may be extended down to about $918 \mathrm{~K}$ [2-8]. The conductivity in the $\alpha$-phase (monoclinic [2, 4,9-11]) which exists from ambient temperature up to the transition point is at least three decades lower $[4,6]$. The ionic transport number was found to be equal to one in the $\delta$-phase [6]; in the $\alpha$-phase an ionic contribution to the conductivity could be detected only near the $\alpha \rightarrow \delta$ transition [4] .

The temperature range at which the materials can be used as a solid electrolyte can be extended by substituting $\mathrm{Bi}_{2} \mathrm{O}_{3}$. Takahashi et al. investigated the electrical properties of $\mathrm{Bi}_{2} \mathrm{O}_{3}$ with several substituents $[6,12-19]$. The region of highly ionic conductive $\delta$-phase (fcc) can be extended to room temperature with a composition of 25-43 mol\% $\mathrm{Y}_{2} \mathrm{O}_{3}$ [13], 35-50 $\mathrm{mol}_{\%} \mathrm{Gd}_{2} \mathrm{O}_{3}$ [16] , $25 \mathrm{~mol}_{\%} \mathrm{WO}_{3}$ [12] , 15-25 mol\% $\mathrm{Nb}_{2} \mathrm{O}_{5}$ and $18-25 \mathrm{~mol} \% \mathrm{Ta}_{2} \mathrm{O}_{5}$ [19]. The conductivity of these solid solutions is lower than that in the $\delta$-phase of pure $\mathrm{Bi}_{2} \mathrm{O}_{3}$. However, the region of the highly ionic conductive phase is extended to room temperature and the sudden volume change at the phase transition is avoided, which is important for practical applications. The conductivity of stabilized bismuth sesquioxides is one decade or more higher than that of stabilized zirconias at the same temperature. However, at higher temperatures these stabilized bismuth sesquioxides show a tendency to be reduced under low oxygen pressures $[6,14]$. At the moment practical applications can be realized in the form of oxygen gauges and oxygen pumps [20] .

From the correlation we found between the ionic radii of the substituents and the amount of substituted M(III) ions necessary to stabilize the $\delta$-phase at room temperature we can conclude that $\mathrm{Bi}_{2} \mathrm{O}_{3}$ substituted with $\mathrm{Er}_{2} \mathrm{O}_{3}$ should be a promising system.

The occurence of the $\delta$-phase at room temperature in the system under consideration for higher 
$\mathrm{Er}_{2} \mathrm{O}_{3}$ concentrations was reported for

$3 \mathrm{Bi}_{2} \mathrm{O}_{3} \cdot \mathrm{Er}_{2} \mathrm{O}_{3}$ by Datta and Meehan [22] and was suggested for $\mathrm{Bi}_{2} \mathrm{O}_{3} \cdot \mathrm{Er}_{2} \mathrm{O}_{3}$ by Nasonova et al. [23]. No other results concerning the phase diagram are reported in the literature. From these points of view the authors have investigated the oxygen ion conduction in sintered oxides of the $\mathrm{Bi}_{2} \mathrm{O}_{3}-\mathrm{Er}_{2} \mathrm{O}_{3}$ system.

The specific purpose of these investigations in the $\mathrm{Bi}_{2} \mathrm{O}_{3}-\mathrm{Er}_{2} \mathrm{O}_{3}$ system is to find a high oxygen ion conductor as electrolyte for 'second generation' oxygen sensors for automotive control (e.g. the device developed by Heyne [21])

\section{Experimental}

\subsection{Preparation and analysis of the specimens}

$\mathrm{Bi}_{2} \mathrm{O}_{3}$ (Merck, very pure) and $\mathrm{Er}_{2} \mathrm{O}_{3}$ (Serva, 99.9\%) were thoroughly mixed and pre-fired at $1020-1120 \mathrm{~K}$ for $16 \mathrm{~h}$, finely ground and isostatically pressed at about $400 \mathrm{MPa}$, sintered in air for $65 \mathrm{~h}$ and cooled down to room temperature at $0.5 \mathrm{~K} \mathrm{~min}^{-1}$. As shown in Table 1, the sintering temperature required to reach densities of $\geq 94 \%$ increased as the content of $\mathrm{Er}_{2} \mathrm{O}_{3}$ was increased. After the synthesis the composition of the samples was checked using X-ray fluorescence; the accuracy of this determination is $0.1 \%$.

The starting materials and two specimens were analysed spectroscopically for small amounts of aluminium and silicon. The amount of aluminium and silicon is important because of their influence on the electrical conductivity, especially in connection with grain boundary effects.

Si was analysed according to the method de-

Table 1. Sintering temperature and density of the specimens

\begin{tabular}{lll}
\hline $\begin{array}{l}\text { Composition } x^{\dagger} \text { in } \\
\left(B i_{2} \mathrm{O}_{3}\right)_{1-\mathrm{x}}\left(\mathrm{Er}_{2} \mathrm{O}_{3}\right)_{\mathrm{x}}\end{array}$ & $\begin{array}{l}\text { Temperature } \\
(\mathrm{K})\end{array}$ & Density \\
\hline $0.025 \sim 0.125$ & 1063 & \\
$0.15 \sim 0.175$ & 1123 & $96 \%$ \\
$0.20 \sim 0.25$ & 1198 & $96 \%$ \\
$0.30 \sim 0.35$ & 1273 & $94 \%$ \\
$0.40 \sim 0.455$ & 1323 & $94 \%$ \\
$0.50 \sim 0.60$ & 1373 & \\
\hline
\end{tabular}

$\dagger x \times 100=\operatorname{mol} \%$

\$ Density is given as a percentage of the theoretical density based on defect fluorite-type lattice veloped in our laboratory [24]. For the analysis of aluminium a new method was developed (see Appendix). The detection limits of these analyses are $0.005 \mathrm{wt} \% \mathrm{Al}$ and $0.001 \mathrm{wt} \% \mathrm{Si}$.

The crystal structures of the specimens were identified with a Philips PW 1370 diffractometer. $\mathrm{CuK} \alpha$ radiation was used with a Ni filter. The lattice parameters were calculated from diffraction angles in the $60-120^{\circ}(2 \theta)$ region, obtained at a scanning speed of $0.25^{\circ} \min ^{-1}$ using $\mathrm{Pb}\left(\mathrm{NO}_{3}\right)_{2}$ as the internal standard.

High temperature X-ray experiments were performed with a Guinier-Lenné camera (heating rate: $5 \mathrm{~K} \mathrm{~h}^{-1}$ ). The $\mathrm{Pt}$ gauze of the sample holder served as a standard, since internal standards could not be used due to the corrosive nature of $\mathrm{Bi}_{2} \mathrm{O}_{3}$.

Differential thermal analysis measurements were performed with a Dupont 990 Thermal Analyzer (heating rate: 10 or $15 \mathrm{~K} \mathrm{~min}^{-1}$ ). A Dupont 951 Thermogravimetric Analyzer was used for investigating various features of defect chemistry. The expansion as a function of temperature was measured with a Leitz dilatometer UBD (heating rate: $1 \mathrm{~K} \mathrm{~min}^{-1}$ ) on sintered rods having a diameter of $4 \mathrm{~mm}$ and a length of $10 \mathrm{~mm}$. The densities of the samples were measured at $298 \mathrm{~K}$ by the standard Archimedes method using mercury.

\subsection{Measurement of the ionic conduction}

The ionic conductivity was examined by measuring the electrical conductivity and the e.m.f. of an oxygen concentration cell. Porous platinum electrodes were sputtered onto the specimens.

The electrical conductivity was measured on cylindrical rods $(3 \mathrm{~mm} \times 4 \mathrm{~mm})$ with a WayneKerr Universal Bridge B221 using the two-probe method. A frequency of $10 \mathrm{kHz}$ was used because the conductivity was nearly frequency independent in the range of $1 \mathrm{kHz}-1 \mathrm{MHz}$. This means that in this case grain size effects play a minor role. This can be expected if the grain size is larger than $20 \mu \mathrm{m}$ and the impurity concentration is relatively low.

The ionic transference number was examined by measuring the e.m.f. of an oxygen gas concentration cell:

$\mathrm{O}_{2}\left(P_{\mathrm{O}_{2}}, \mathrm{a}\right)$, Pt $\mid$ specimen disc $(10 \mathrm{~mm} \times 2 \mathrm{~mm}) \mid \mathrm{Pt}$,

$$
\mathrm{O}_{2}\left(P_{\mathrm{O}_{2}, \mathrm{~b}}\right)
$$




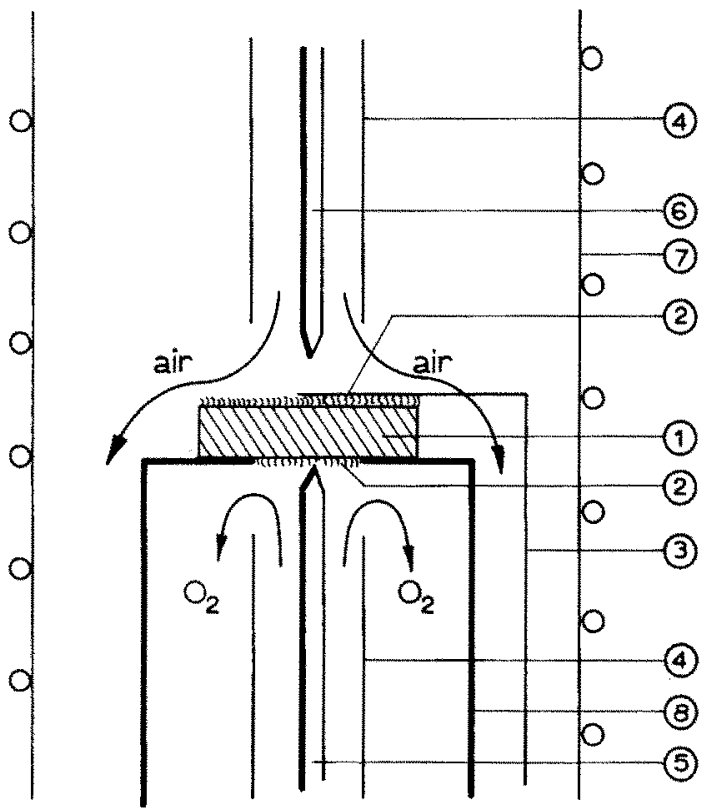

Fig. 1. Construction of the concentration cell. 1 specimen; 2 porous Pt-electrode; 3 Pt-lead; 4,8 quartz tube; 5,6 $\mathrm{Pt} / \mathrm{Pt}, 10 \% \mathrm{Rh}$ thermocouple; 7 furnace wall.

where $P_{\mathrm{O}_{2, \mathrm{a}}}=0.21 \mathrm{~atm}$ (air) and $P_{\mathrm{O}_{2}, \mathrm{~b}}=1.00 \mathrm{~atm}$ (pure oxygen).

If the conduction is purely ionic the e.m.f. $E_{0}$ of this cell is given by

$$
E_{0}=\frac{R T}{4 F} \ln \left(P_{\mathrm{O}_{2}, \mathrm{~b}}\right) /\left(P_{\mathrm{O}_{2}, \mathrm{a}}\right) .
$$

In a mixed conductor the e.m.f. is lowered due to the electronic conduction and the average ion transference number is given by:

$$
t_{\mathrm{i}}=\frac{\sigma_{\mathrm{i}}}{\sigma_{\mathrm{i}}+\sigma_{\mathrm{e}}}=\frac{E}{E_{0}}
$$

where $\sigma_{\mathrm{i}}$ is the ionic conduction, $\sigma_{\mathrm{e}}$ the electronic conduction and $E$ is the measured e.m.f.

Fig. 1 shows the construction of the concentration cell (a vertical apparatus), a detailed figure will be given by T. v. Dijk et al. [25].

\section{Results and discussion}

\subsection{Samples prepared}

As shown in Table 1 the densities of the specimens after sintering were $94-96 \%$ of the theoretical density. The average grain size of all the samples was about $30 \mu \mathrm{m}$. The difference between the
Table 2. Concentration of the aluminium and silicon impurities in the starting materials and specimens

\begin{tabular}{lrl}
\hline Sample & $w t \% \mathrm{Si}$ & $w t \%$ Al \\
\hline $\mathrm{Bi}_{2} \mathrm{O}_{3}$ & $\leqslant 0.001$ & 0.03 \\
$\mathrm{Er}_{2} \mathrm{O}_{3}$ & 0.003 & 0.02 \\
$\left(\mathrm{Bi}_{2} \mathrm{O}_{3}\right)_{0.50}\left(\mathrm{Er}_{2} \mathrm{O}_{3}\right)_{0.20}$ & 0.008 & 0.03 \\
$\left(\mathrm{Bi}_{2} \mathrm{O}_{3}\right)_{0.545}\left(\mathrm{Er}_{2} \mathrm{O}_{3}\right)_{0.455}$ & 0.010 & 0.02 \\
\hline
\end{tabular}

calculated composition and the measured composition (X-ray fluorescence) of the specimens was $0.2 \%$ or less. The colour of the specimens changed from orange for $2.5 \mathrm{~mol} \% \mathrm{Er}_{2} \mathrm{O}_{3}$ through yellow for $15 \mathrm{~mol}_{\%} \mathrm{Er}_{2} \mathrm{O}_{3}$ to brown for the specimens with 30-60 mol\% $\mathrm{Er}_{2} \mathrm{O}_{3}$. Quenched specimens were orange in most cases.

Table 2 gives the concentration of the aluminium and silicon impurities of the analysed samples. It is easy to see that the aluminium impurities in the specimens are found in the starting materials whereas the silicon impurities are mainly introduced during the synthesis; possibly the grinding procedure.

The strength of the ceramic samples containing $15-25 \mathrm{~mol}_{2} \mathrm{Er}_{2} \mathrm{O}_{3}$ is relatively low, possibly due to strain.

\subsection{Structural aspects}

Table 3 gives a survey of the existing structure(s) if the specimens are subjected to different heat treatments. In the 'quenching' procedure the samples were suddenly removed from the furnace and cooled to room temperature by natural convection with the result that the high temperature structure may be retained. This can be avoided by cooling down the specimens very slowly $\left(0.5 \mathrm{~K} \mathrm{~min}^{-1}\right)$. In order to ensure that the high temperature structures are retained during cooling down by $0.5 \mathrm{~K} \mathrm{~min}^{-1}$ the specimens were annealed for $250 \mathrm{~h}$ at $898 \mathrm{~K}$.

The monophasic $\mathrm{fcc}$ structure was observed at low temperatures for samples containing 17.5-45.5 mol\% $\mathrm{Er}_{2} \mathrm{O}_{3}$. As shown in Fig. 2 the lattice constants of the specimens decrease with an increase in the content of $\mathrm{Er}_{2} \mathrm{O}_{3}$. Vegard's rule holds in this composition range, which means that over this range an $\mathrm{fcc}$ solid solution is found. Below $17.5 \mathrm{~mol}_{\%} \mathrm{Er}_{2} \mathrm{O}_{3}$ and above $45.5 \mathrm{~mol} \% \mathrm{Er}_{2} \mathrm{O}_{3}$ 
Table 3. Survey of the structural data of the $\mathrm{Bi}_{2} \mathrm{O}_{3}-\mathrm{Er}_{2} \mathrm{O}_{3}$ system

\begin{tabular}{|c|c|c|c|}
\hline \multirow{2}{*}{$\begin{array}{l}x \text { in } \\
\left(\mathrm{Bi}_{2} \mathrm{O}_{3}\right)_{1-x}\left(\mathrm{Er}_{2} \mathrm{O}_{3}\right)_{x}\end{array}$} & \multicolumn{3}{|c|}{ Temperature treatment } \\
\hline & $\begin{array}{l}\text { 'Quenched' from the } \\
\text { sintering temperature }\end{array}$ & $\begin{array}{l}\text { Cooled down } \\
\text { by } 0.5 \mathrm{~K} \mathrm{~min}^{-1}\end{array}$ & $\begin{array}{l}\text { Annealed for } \\
250 \mathrm{~h} \text { at } 898 \mathrm{~K}\end{array}$ \\
\hline 0.025 & $\alpha+\beta^{+}+$ & $\beta$ & $\alpha+\beta$ \\
\hline 0.05 & $\beta$ & $\beta$ & $\alpha+\beta$ \\
\hline 0.075 & $\beta$ & $\beta^{*} \S$ & $\mathbf{\alpha}+\delta$ \\
\hline 0.10 & $\beta^{*}$ & $\beta^{*}$ & $\alpha+\delta$ \\
\hline 0.125 & $\delta *$ & $\delta$ & $\boldsymbol{\alpha}+\hat{o}+\mathbf{\varepsilon}$ \\
\hline 0.15 & $\delta$ & $\delta$ & $\alpha+\delta+\beta+\varepsilon$ \\
\hline $0.175 \sim 0.455$ & $\delta$ & $\delta$ & $\delta$ \\
\hline $0.50 \sim 0.60$ & $\delta+\mathrm{Er}_{2} \mathbf{O}_{3}$ & $\delta+\mathbf{E r}_{2} \mathbf{O}_{3}$ & $\delta+\mathrm{Er}_{2} \mathrm{O}_{3}$ \\
\hline
\end{tabular}

+ The $\beta$-phase has a tetragonal structure $[2,4,9,7]$

\$ The structures shown in bold appear in minor concentrations

$\S$ An asterisk means that the structure is distorted

II In this table $\epsilon$ denotes the rhombohedral structure

polyphasic regions appear. Further study is necessary to determine the exact location of the phase boundaries and the temperatures of the phase transition in these regions. In this study these regions are not investigated in detail.

These results agree with the observation of Datta and Meehan [22] who reported the existence of the fcc phase for $3 \mathrm{Bi}_{2} \mathrm{O}_{3} \cdot \mathrm{Er}_{2} \mathrm{O}_{3}$, while the existence of the fcc phase for $\mathrm{Bi}_{2} \mathrm{O}_{3} \cdot \mathrm{Er}_{2} \mathrm{O}_{3}$ as suggested by Nasonova et al. [23] is not confirmed by our study.

As a result of this study we did find that the percentage of $\mathrm{Er}_{2} \mathrm{O}_{3}$ necessary to stabilize the $\mathrm{fcc}$ structure of $\mathrm{Bi}_{2} \mathrm{O}_{3}$ at low temperatures is the lowest percentage substituent known in literature for valence (III) lanthanides as substituents $[6,13-16]$. For valence $(V)$ substituents $15 \mathrm{~mol} \%$ $\mathrm{Nb}_{2} \mathrm{O}_{5}$ and $18 \mathrm{~mol} \% \mathrm{Ta}_{2} \mathrm{O}_{5}$ is necessary to stabilize the $f(c)$ phase [19].

Theoretical densities of these materials have been calculated from the measured lattice constants (see Fig. 2), making use of three possible models:

1. all cations occupy their normal sites in the fluorite structure and there are two vacancies to a unit cell, i.e. $\mathrm{Bi}_{4(1-x)} \mathrm{Er}_{4 x} \mathrm{O}_{6} \square_{2}$.

2. all cations occupy their normal sites in the fluorite structure and the vacancies are occupied by oxygen ions:

$$
\mathrm{O}_{2}+2 \mathrm{a} \rightarrow 2 \mathrm{O}^{2-}+4 \mathrm{~h}^{+}
$$

where $\mathrm{h}^{+}$denotes a hole; i.e. $\mathrm{Bi}_{4(1-x)} \mathrm{Er}_{4 x} \mathrm{O}_{8}$
3. all $\mathrm{Bi}^{3+}$ ions occupy their normal sites in the fluorite structure and the $\mathrm{Er}^{3+}$ ions occupy interstitial sites, i.e. $\mathrm{Bi}_{4} \mathrm{Er}_{4 x /(1-x)} \mathrm{O}_{6 /(1-x)}$.

Comparing the calculated densities and the observed densities, as given in Fig. 3, we can see that model 3 is quite improbable. SEM photographs showed that the specimens had only a slight porosity, so model 2 is incorrect. Model 2 appeared to be incorrect because concentration cell measurements showed oxygen ion conduction and no hole conduction (see Section 3.4). Furthermore with a thermobalance a negligible weight increase was detected during the solid state reaction of $\mathrm{Bi}_{2} \mathrm{O}_{3}$ and $\mathrm{Er}_{2} \mathrm{O}_{3}$ on heating in air. Consequently model 1 is the most likely.

\subsection{The conductivity of the sintered specimens}

The conductivity of the sintered $\mathrm{Bi}_{2} \mathrm{O}_{3}-\mathrm{Er}_{2} \mathrm{O}_{3}$

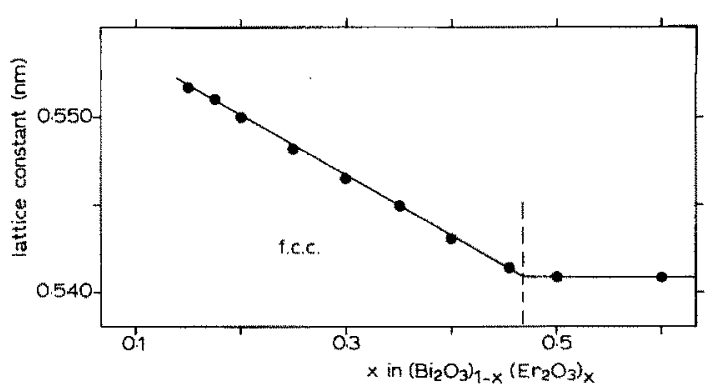

Fig. 2. Lattice constant of the fee phase of the specimens cooled from the sintering temperature by $0.5 \mathrm{~K} \mathrm{~min}^{-1}$ to room temperature. 


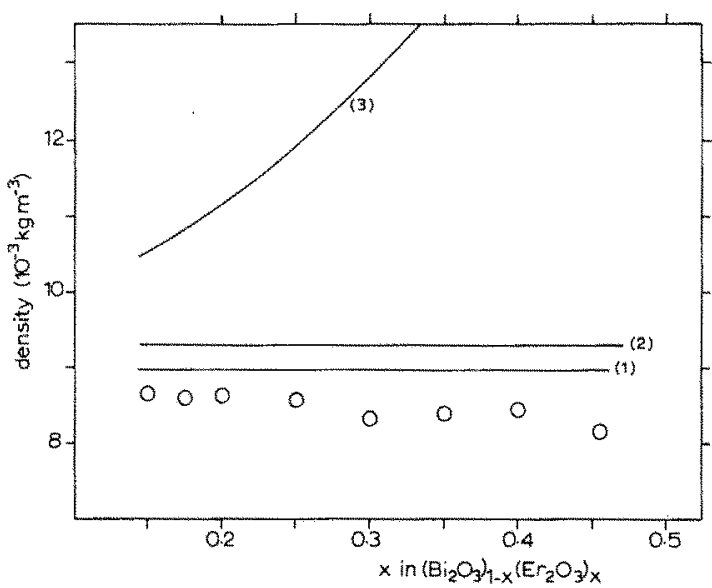

Fig. 3. Observed densities and calculated densities fot various crystal models: (1) for model $\mathrm{Bi}_{4(1-x)} \mathrm{Er}_{4 x} \mathrm{O}_{6} \mathrm{a}_{2}$; (2) for model $\mathrm{Bi}_{4(1-x)} \mathrm{Er}_{4 x} \mathrm{O}_{5} ;(3)$ for model $\mathrm{Bi}_{4} \mathrm{Et}_{4, x / 1-x)} \mathrm{O}_{6 /(1-x)}$. The open circles represent the measured densities.

specimens measured in air is shown in Figs. 4 and 5 as Arrhenius plots. In these figures the conductivity of pure $\mathrm{Bi}_{2} \mathrm{O}_{3}$ (Takahashi et al. [6]) is given as a reference material. Table 4 gives the values of the activation energies $E_{\mathrm{a}}$ and the pre-exponential terms $\sigma_{0}$ for the Arrhenius plots of the conductivity, while the deviation is given in the $90 \%$ reliability interval.

\subsubsection{Conductivity of the samples with 15 and} $17.5 \mathrm{~mol}^{\circ} \mathrm{Er}_{2} \mathrm{O}_{3}$. The specimens containing 15

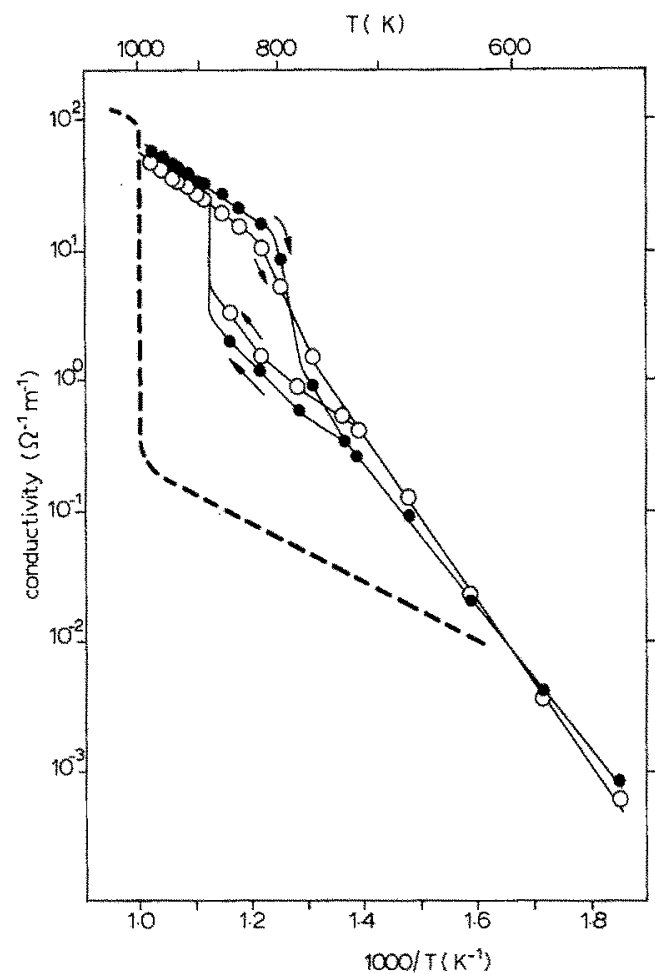

Fig. 4. Conductivity of $\left(\mathrm{Bi}_{2} \mathrm{O}_{3}\right)_{1-x}\left(\mathrm{Er}_{2} \mathrm{O}_{3}\right)_{x}$ in air. $\bullet, x=0.15 ; 0, x=0.175$. The broken line represents the conductivity of pure $\mathrm{Bi}_{2} \mathrm{O}_{3}$.

and $17.5 \mathrm{~mol}_{2} \% \mathrm{Er}_{2} \mathrm{O}_{3}$ at $(738 \pm 10) \mathrm{K}$ show a change in the activation energy of the conductivity and at $(878 \pm 10) \mathrm{K}$ there is a sudden increase in the conductivity (see Fig. 4). In the cooling

Table 4. Activation energies and pre-exponential terms for the Arrhenius plots of the conductivity of the fec phase

\begin{tabular}{|c|c|c|c|c|c|}
\hline \multirow[t]{2}{*}{$\frac{x i n}{\left(B i_{2} O_{3}\right)_{1-x}\left(\operatorname{Er}_{2} O_{3}\right)_{x}}$} & \multicolumn{2}{|c|}{$\begin{array}{l}\text { High temperature range } \\
>873 \mathrm{~K}\end{array}$} & \multicolumn{3}{|c|}{$\begin{array}{l}\text { Low temperature range } \\
<823 K\end{array}$} \\
\hline & $\log \sigma_{0}\left(\Omega^{-1} \mathrm{~m}^{-1}\right)$ & $E_{a}\left(\mathrm{~kJ} \mathrm{~mol}^{-1}\right)$ & $\log \sigma_{0}\left(\Omega^{-1} \mathrm{~m}^{-1}\right)$ & $E_{a}(\mathrm{k}$ & $\left.\mathrm{J} \mathrm{mol}{ }^{-1}\right)$ \\
\hline 0.15 & $4.8 \pm 0.1$ & $56 \pm 2$ & $7.0 \pm 0.2 t$ & 104 & $\pm 3 \dagger$ \\
\hline 0.175 & $5.4 \pm 0.7$ & $68 \pm 10$ & $8.1 \pm 0.3$ & 118 & \pm 4 \\
\hline 0.20 & $4.9 \pm 0.2$ & $62 \pm 3$ & $8.11 \pm 0.04$ & 114.6 & $5 \pm 0.5$ \\
\hline 0.25 & $5.25 \pm 0.04$ & $72 \pm 4$ & $7.90 \pm 0.06$ & 117 & \pm 1 \\
\hline 0.30 & $6.93 \pm 0.09$ & $108 \pm 1$ & $6.93 \pm 0.09$ & 108 & \pm 1 \\
\hline 0.35 & $6.7 \pm 0.2$ & $109 \pm 2$ & $6.7 \pm 0.2$ & 109 & \pm 2 \\
\hline 0.40 & $6.1 \pm 0.1$ & $111 \pm 2$ & $6.1 \pm 0.1$ & 111 & \pm 2 \\
\hline 0.455 & $6.3 \pm 0.2$ & $117 \pm 3$ & $6.3 \pm 0.2$ & 117 & \pm 3 \\
\hline 0.50 & $6.3 \pm 0.2$ & $120 \pm 3$ & $6.3 \pm 0.2$ & 120 & \pm 3 \\
\hline 0.60 & $6.3 \pm 0.2$ & $124 \pm 3$ & $6.3 \pm 0.2$ & 124 & \pm 3 \\
\hline
\end{tabular}

+ Between $748-873 \mathrm{~K}$ these values are: $\log \sigma_{0}=6.40 \pm 0.04 \Omega^{-1} \mathrm{~cm}^{-1}, E_{\mathrm{a}}=84 \pm 1 \mathrm{~kJ} \mathrm{~mol}^{-1}$; the deviation of these values is given in the $65 \%$ reliability interval.

† Between 748-873 K these values are: $\log \sigma_{0}=6 \pm 1 \Omega^{-1} \mathrm{~cm}^{-1}, E_{\mathrm{a}}=87 \pm 10 \mathrm{~kJ} \mathrm{~mol}^{-1}$; the deviation of these values is given in the $65 \%$ reliability interval. 
Table 5. Survey of the results of the investigations performed on specimens containing 15 and $17.5 \mathrm{~mol}^{2} \mathrm{Er}_{2} \mathrm{O}_{3}$

\begin{tabular}{|c|c|c|}
\hline Method & $\begin{array}{c}15 \mathrm{~mol}_{\mathrm{E}}^{\mathrm{Er}_{2} \mathrm{O}_{3}} \\
(\mathrm{~K})\end{array}$ & $\begin{array}{l}17.5 \mathrm{~mol}_{(\mathrm{K})} \mathrm{Er}_{2} \mathrm{O}_{3} \\
\end{array}$ \\
\hline \multicolumn{3}{|l|}{ Conductivity $(\uparrow)$} \\
\hline change in $E_{\mathrm{a}}$ & $730 \pm 10$ & $730 \pm 10$ \\
\hline sudden increase in $\sigma$ & $878 \pm 10$ & $878 \pm 10$ \\
\hline \multicolumn{3}{|l|}{ Conductivity $(\downarrow)$} \\
\hline strong decrease in $\sigma$ & $800-740$ & $830-770$ \\
\hline \multicolumn{3}{|l|}{ HT Guinier $(\uparrow)$} \\
\hline broadened reflections & $750-840$ & $750-840$ \\
\hline$\delta \rightarrow \beta^{*}$ & $841 \pm \quad 5$ & $843 \pm 5$ \\
\hline$\beta^{*} \rightarrow \delta^{*}$ & $878 \pm$ & $883 \pm$ \\
\hline \multicolumn{3}{|l|}{ Thermal expansion $(\uparrow)$} \\
\hline decrease in $\alpha$ & $763 \pm 10$ & $778 \pm 10$ \\
\hline region of temperature- & $849 \pm 5$ & $841 \pm 5$ \\
\hline dependent $\alpha$ & $880 \pm$ & $869 \pm$ \\
\hline \multicolumn{3}{|l|}{ Thermal expansion ( $\downarrow$ ) } \\
\hline region of temperature- & $776 \pm 5$ & $803 \pm 10$ \\
\hline dependent $\alpha$ & $743 \pm 10$ & \\
\hline
\end{tabular}

direction changes appear with a large hysteresis. For the sample containing $15 \mathrm{~mol}_{\%} \mathrm{Er}_{2} \mathrm{O}_{3}$ these effects cannot be ascribed to phase segregation (compare Table 3 ) because this process is too slow in order to take place during the conductivity measurements. This temperature behaviour was also investigated with high-temperature Guinier (HT Guinier), thermal expansion and differential thermal analysis (DTA). A survey of the results is given in Table 5.

During heating with HT Guinier a broadening of various reflections was observed, however, the $(h h h)$ reflections are not broadened. At about $840 \mathrm{~K}$ these broadened reflections transform to distinct lines which are typical for a tetragonal distortion $\left(\beta^{*}\right)$. This indicates that the broadened reflections are due to a tetragonal distortion which is too small (less than $0.2 \%$ ) to be measured with HT Guinier. This distortion becomes larger with increasing temperature.

At about $880 \mathrm{~K}$ the $\beta^{*}$-phase transforms into an fcc-phase $\left(\delta^{*}\right)$, which has a larger lattice constant than the $\delta$-phase.

In the cooling direction no X-ray recording was performed due to Pt-contamination from the gauze at high temperatures of about $900 \mathrm{~K}$. After heating to $950 \mathrm{~K}$ we determined about $2 \% \mathrm{Pt}$ in our specimen (X-ray fluorescence) and this Pt- contamination may greatly influence phase transitions [4].

The thermal expansion of the specimen containing 15 mol\% $\mathrm{Er}_{2} \mathrm{O}_{3}$ is shown in Fig. 6. The shapes of the curves are identical to those of the specimen containing $17.5 \mathrm{~mol} \% \mathrm{Er}_{2} \mathrm{O}_{3}$, but the measured effects are smaller.

In the heating direction a decrease in the expansion coefficient $\alpha$ (see arrow) was observed for both samples. In the temperature region of about $845-875 \mathrm{~K}$ the apparent value of $\alpha$ is strongly temperature dependent, while at higher temperatures the value of $\alpha$ is again constant (Fig. 6 , Table 5), and has about the same value as in the low temperature region. In the cooling direction the changes in the $\alpha-T$ curve appear with a large hysteresis.

DTA revealed no heat effects, which means that they are either very small or are smeared out.

Comparing the data on structural effects with that on conductivity measurements we notice that the temperature region of $730-878 \mathrm{~K}$ in which there is a change in $E_{\mathrm{a}}$ agrees well with the region of $750-880 \mathrm{~K}$ measured by HT Guinier and the region of $763-875 \mathrm{~K}$ measured by thermal expansion. Arguments are the overlap of different temperature intervals with coinciding hightemperature boundaries and the continuous 


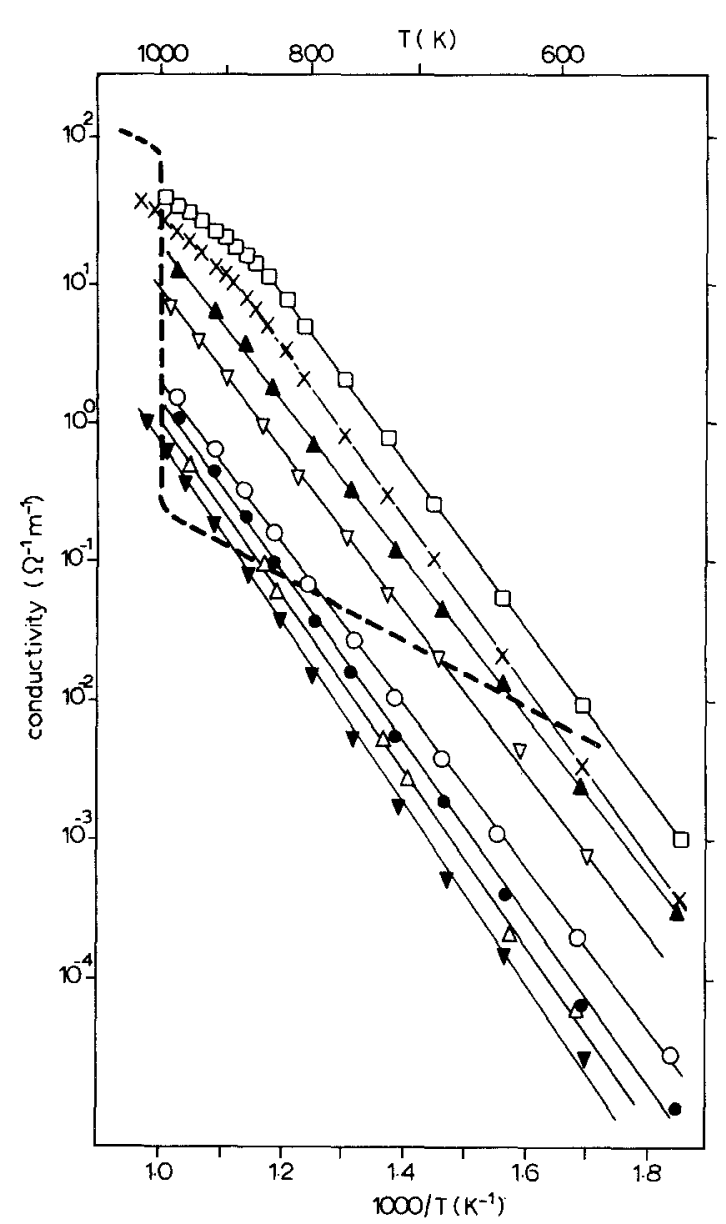

Fig. 5. Conductivity of $\left(\mathrm{Bi}_{2} \mathrm{O}_{3}\right)_{1-x}\left(\mathrm{Er}_{2} \mathrm{O}_{3}\right)_{x}$ in air. $a, x=$ $0.20 ; \mathrm{x}, x=0.25 ; \star, x=0.30 ; \nabla, x=0.35 ; \circ, x=0.40$; $\bullet, x=0.455 ; \triangle, x=0.50 ; \nabla, x=0.60$. The broken line represents the conductivity of pure $\mathrm{Bi}_{2} \mathrm{O}_{3}$.

(smooth) character at the low-temperature side. The electrical measurements suggest that the tetragonal distortion already starts at $730 \mathrm{~K}$, which could not be measured with HT Guinier and thermal expansion. At $840 \mathrm{~K}$ the value of the tetragonal distortion is large enough to be

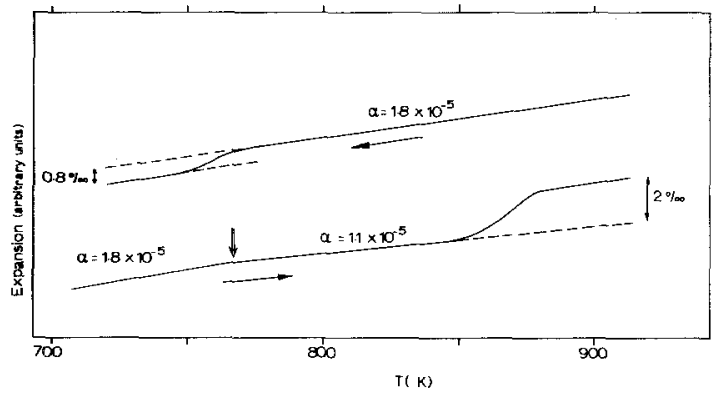

Fig. 6. Heating-up and cooling-down curves as measured with a dilatometer for $\left(\mathrm{Bi}_{2} \mathrm{O}_{3}\right)_{0.85}\left(\mathrm{Er}_{2} \mathrm{O}_{3}\right)_{0.15}$. measured and increase strongly with temperature, which agrees with the thermal expansion data (see Table 5).

The sudden increase in the conductivity at $878 \mathrm{~K}$ is caused by the structural change from a tetragonal to a cubic phase and at this temperature the value of the expansion coefficient $\alpha$ becomes temperature independent.

The strong decrease in $\alpha$ in the cooling direction can be correlated with the region having a temperature dependent $\alpha$.measured by thermal expansion.

\subsubsection{Conductivity of samples containing}

20 mol\% or more $\mathrm{Er}_{2} \mathrm{O}_{3}$. The sintered oxides containing 20 mol\% or more $\mathrm{Er}_{2} \mathrm{O}_{3}$ show no jump in the conductivity in the whole range of temperatures examined. However the samples containing $20 \mathrm{~mol} \%$ and $25 \mathrm{~mol} \% \mathrm{Er}_{2} \mathrm{O}_{3}$ showed at about $870 \mathrm{~K}$ a knee in the Arrhenius plot, this corresponds to a change in the activation energy and the pre-exponential term, as can be seen from Fig. 5 and Table 4. Takahashi et al. found such a knee at about the same temperature for the samples containing 25-33 mol\% $\mathrm{Y}_{2} \mathrm{O}_{3}$ [13], $35-40 \mathrm{~mol}_{\%} \mathrm{Gd}_{2} \mathrm{O}_{3}$ [16], and $15 \mathrm{~mol} \% \mathrm{Nb}_{2} \mathrm{O}_{5}$ [19]. Bauerle et al. [26] and Casselton [27] reported a knee in the Arrhenius plot of yttria stabilized zirconia at about $1070 \mathrm{~K}$; they ascribe this knee to a changing conductivity mechanism. The activation energy changed from $112.8 \mathrm{~kJ}$ $\mathrm{mol}^{-1}$ to $65.8 \mathrm{~kJ} \mathrm{~mol}^{-1}$ [26]. The absolute values as well as the change in activation energy corresponds with our values and the values measured by Takahashi [13].

Our HT Guinier experiments on $\mathrm{Bi}_{2} \mathrm{O}_{3}$ based systems revealed that at this temperature the $\mathrm{fcc}$ phase $\delta$, transforms to an fcc-phase with a larger lattice constant. The increase of the lattice constant for $\left(\mathrm{Bi}_{2} \mathrm{O}_{3}\right)_{0.80}\left(\mathrm{Er}_{2} \mathrm{O}_{3}\right)_{0.20}$ is in the order of $1.5 \%$. We observed the same phenomena for $\left(\mathrm{Bi}_{2} \mathrm{O}_{3}\right)_{0.75}\left(\mathrm{Er}_{2} \mathrm{O}_{3}\right)_{0.25}$ and $\left(\mathrm{Bi}_{2} \mathrm{O}_{3}\right)_{0.75}$ $\left(\mathrm{Y}_{2} \mathrm{O}_{3}\right)_{0.25}$, however the increase in lattice constant was too small to be measured accurately. Therefore we can conclude that the change in activation energy is correlated to a change of the lattice constant.

An increase in the lattice constant of the rhombohedral phase in the system $\left(\mathrm{Bi}_{2} \mathrm{O}_{3}\right)_{1-x}$ $(\mathrm{SrO})_{x}$ with $x=0.18-0.43$ is reported by 
Guillermo et al. [28] at about $950-985 \mathrm{~K}$ and in the system $\left(\mathrm{Bi}_{2} \mathrm{O}_{3}\right)_{1-x}(\mathrm{CaO})_{x}$ with $x=$ $0.22-0.31$ by Conflant et al. [29] at about $1000-1010 \mathrm{~K}$. Takahashi et al. [6] measured a sudden increase in the conductivity for samples containing $20-40 \mathrm{~mol} \% \mathrm{SrO}$ at about the same temperature as the increase in the lattice constant.

An increase in the unit-cell volume of the cubic fcc phase with constant oxygen ion concentration suggests the possibility of a decrease in the contributions of the local strain component during the passage of oxygen ions through the lattice which leads to a decrease in the activation energy. Before firm conclusions on these aspects can be drawn more has to be known about changes in the ordering of oxygen in the lattice. Details of this subject are under investigation.

In Fig. 7 the oxygen ion conductivity in the $\mathrm{Bi}_{2} \mathrm{O}_{3}-\mathrm{Er}_{2} \mathrm{O}_{3}$ system is plotted against the $\mathrm{Er}_{2} \mathrm{O}_{3}$ content at different temperatures. The conductivity of $\left(\mathrm{Bi}_{2} \mathrm{O}_{3}\right)_{0.75}\left(\mathrm{Y}_{2} \mathrm{O}_{3}\right)_{0.25}[13]$ is given as a reference.

At $573 \mathrm{~K}$ and $973 \mathrm{~K}$ the logarithm of the conductivity decreases almost linearly with the $\mathrm{Er}_{2} \mathrm{O}_{3}$ content, whereas between $673 \mathrm{~K}$ and $873 \mathrm{~K}$ a maximum appears in the conductivity at $20 \mathrm{~mol} \%$ $\mathrm{Er}_{2} \mathrm{O}_{3}$. Such a maximum in the fcc-phase region

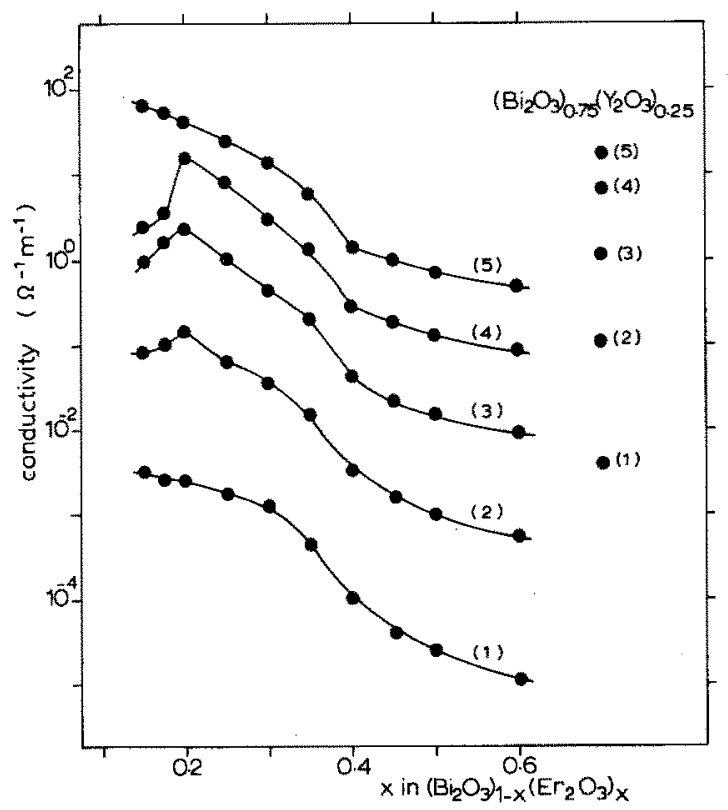

Fig. 7. Conductivity versus composition at different temperatures. The conductivity of $\left(\mathrm{Bi}_{2} \mathrm{O}_{3}\right)_{0.75}\left(\mathrm{Y}_{2} \mathrm{O}_{3}\right)_{0.25}$ is given as a reference. (1) $573 \mathrm{~K}$; (2) $673 \mathrm{~K}$; (3) $773 \mathrm{~K}$; (4) $873 \mathrm{~K}$; (5) $973 \mathrm{~K}$. has never before been reported in the literature for investigations on the $\mathrm{Bi}_{2} \mathrm{O}_{3}$ system $[6,12-19]$.

To understand this maximum it is necessary to know more about the discontinuities in the conductivity of the samples containing 15-25 mol\% $\mathrm{Er}_{2} \mathrm{O}_{3}$. Possibly the nature of this maximum can be related to the maximum in the conductivity in the $\mathrm{ZrO}_{2}-\mathrm{Y}_{2} \mathrm{O}_{3}$ system at concentrations of about $7 \mathrm{~mol} \%$ as reported, by several authors [30].

Finally it should be mentioned that $\left(\mathrm{Bi}_{2} \mathrm{O}_{3}\right)_{0.80}$ $\left(\mathrm{Er}_{2} \mathrm{O}_{3}\right)_{0.20}$ is the best oxygen ion conductor yet found. The conductivity at $773 \mathrm{~K}$ and $973 \mathrm{~K}$ is $2.3 \Omega^{-1} \mathrm{~m}^{-1}$ and $37 \Omega^{-1} \mathrm{~m}^{-1}$ respectively. The best conductors found by Takahshi were

$\left(\mathrm{Bi}_{2} \mathrm{O}_{3}\right)_{0.75}\left(\mathrm{Y}_{2} \mathrm{O}_{3}\right)_{0.25}$ and $\left(\mathrm{Bi}_{2} \mathrm{O}_{3}\right)_{0.85}\left(\mathrm{Nb}_{2} \mathrm{O}_{3}\right)_{0.15}$, the conductivity at $773 \mathrm{~K}$ is $1.2 \Omega^{-1} \mathrm{~m}^{-1}$ and $1.1 \Omega^{-1} \mathrm{~m}^{-1}$ respectively and at $973 \mathrm{~K} 16 \Omega^{-1} \mathrm{~m}^{-1}$ and $19 \Omega^{-1} \mathrm{~m}^{-1}[13,19]$. The conductivity of $\left(\mathrm{Bi}_{2} \mathrm{O}_{3}\right)_{0.80}\left(\mathrm{Er}_{2} \mathrm{O}_{3}\right)_{0.20}$ is about $50-100$ times higher than the conductivity of $\left(\mathrm{ZrO}_{2}\right)_{0.915}$ $\left(\mathrm{Y}_{2} \mathrm{O}_{3}\right)_{0.085}$ at the same temperatures.

\subsection{Ionic transport number measurements}

In order to determine the charge carriers in these conductors, measurements were performed with an oxygen gas concentration cell. Table 6 shows the ratio of the measured e.m.f. to the theoretical e.m.f. of cell 1 . These results indicate that the electrical conduction in the specimens can be almost wholly attributed to the oxygen ion. For the specimens containing 40 mol\% or more $\mathrm{Er}_{2} \mathrm{O}_{3}$ there is an electronic component at low temperatures.

\section{Conclusions}

High oxygen ion conduction is found in sintered oxides of the $\mathrm{Bi}_{2} \mathrm{O}_{3}-\mathrm{Er}_{2} \mathrm{O}_{3}$ system. The ionic transference number was found to be equal to one for samples containing $17.5-30 \mathrm{~mol} \% \mathrm{Er}_{2} \mathrm{O}_{3}$. Samples containing 40-60 mol\% $\mathrm{Er}_{2} \mathrm{O}_{3}$ showed an electronic component at low temperatures.

The highly conductive f $\mathrm{c}$ phase was stable at low temperatures for substituent concentrations between $17.5-45.5 \mathrm{~mol} \% \mathrm{Er}_{2} \mathrm{O}_{3}$. The lower boundary of this region is the smallest percentage valence (III) substituent known in literature which can stabilize the fce structure at low temperatures.

Between $673-873 \mathrm{~K}$ a maximum in the conduc- 
Table 6. Ratios of the measured e.m.f. $\mathrm{E}$ to the theoretical value $\mathrm{E}_{0}$ of the following cell: $\mathrm{O}_{2}(0.21 \mathrm{~atm}), \mathrm{Pt}\left|\left(\mathrm{Bi}_{2} \mathrm{O}_{3}\right)_{1-\mathrm{x}}\left(\mathrm{Er}_{2} \mathrm{O}_{3}\right)_{\mathrm{x}}\right| \mathrm{Pt}, \mathrm{O}_{2}(1 \mathrm{~atm})$ at different temperatures

\begin{tabular}{llllllll}
\hline & \multicolumn{7}{c}{${\mathrm{E} / \mathrm{E}_{0}}$} \\
\cline { 2 - 8 } $\mathrm{x}$ & $773 K$ & $823 K$ & $873 K$ & $923 K$ & $973 K$ & $1023 K$ & $1073 K$ \\
\hline 0.175 & - & 0.98 & 0.99 & 1.00 & 1.01 & 1.02 & 1.00 \\
0.20 & 0.98 & 1.02 & 0.98 & 0.99 & 0.99 & 0.99 & 0.97 \\
0.30 & - & 0.99 & 1.02 & 1.03 & 1.04 & 1.03 & 1.02 \\
0.40 & - & - & 0.93 & 0.96 & 1.00 & 1.01 & 1.01 \\
0.50 & 0.87 & 0.92 & 0.95 & 0.96 & 0.97 & 0.97 & 0.97 \\
0.60 & - & 0.95 & 0.95 & 0.96 & 0.98 & 0.98 & 0.98 \\
\hline
\end{tabular}

tivity was found at $20 \mathrm{~mol} \% \mathrm{Er}_{2} \mathrm{O}_{3}$. The most desirable composition in this system is $\left(\mathrm{Bi}_{2} \mathrm{O}_{3}\right)_{0.80}$ $\left(\mathrm{Er}_{2} \mathrm{O}_{3}\right)_{0.20}$, since the fcc phase is stable at low temperatures and has the highest conductivity over a wide range of temperatures. The conductivity of this specimen is about 2 to 3 times higher than the conductivity of the best oxygen ion conductors reported for $\mathrm{Bi}_{2} \mathrm{O}_{3}$-based solid solutions and is about 50-100 times higher than the conductivity of stabilized zirconia $\left(\mathrm{ZrO}_{2}\right)_{0.915}\left(\mathrm{Y}_{2} \mathrm{O}_{3}\right)_{0.085}$ at the same temperature.

We can conclude that sintered oxides of the $\mathrm{Bi}_{2} \mathrm{O}_{3}-\mathrm{Er}_{2} \mathrm{O}_{3}$ system are promising materials for oxygen gauges and pumps.

\section{Appendix}

Small amounts of aluminium were analysed in the following way.

A $100 \mathrm{mg}$ specimen was dissolved in $25 \mathrm{~cm}^{3}$ hydrochloric acid $(1: 10)$ and transferred into a $50 \mathrm{~cm}^{3}$ volumetric flask. $25 \mathrm{~cm}^{3}$ of the diluted solution was added to a column (the cationexchange column is pre-treated with $100 \mathrm{~cm}^{3} 6 \mathrm{M}$ hydrochloric acid and afterwards with $60 \mathrm{~cm}^{3}$ $0.5 \mathrm{M}$ hydrochloric acid) and the bismuth eluted with $5 \times 10 \mathrm{~cm}^{3} 0.5 \mathrm{M}$ hydrochloric acid. Subsequently the resin bed was washed, with $125 \mathrm{~cm}^{3}$ of $3 \mathrm{M}$ hydrochloric acid in $50 \%$ ethanol and this eluant was collected in a $500 \mathrm{~cm}^{3}$ volumetric flask. The aluminium in this solution was then determined [34].

\section{Acknowledgements}

The authors are much indebted to Mr. H. Kruidhof for developing a new method for analysing small amounts of aluminium and for performing the chemical analyses. We would like to express our appreciation to $\mathrm{Mr} \mathrm{J}$. Boeysma for performing the HT Guinier experiments. Financial assistance from Philips N.V. (Elcoma) is gratefully acknowledged.

\section{References}

[1] G. Gattow and H. Schröder, Z, Anorg. Allg. Chem. $318(1962) 176$.

[2] E. M. Levin and R. S. Roth, J. Res. Nat. Bur. Std. 68A (2) (1964) 189.

[3] E. M. Levin and C. R. McDaniel ibid 69A (3) (1965) 237.

[4] H. A. Harwig, thesis, State University, Utrecht (1977).

[5] C. N.R. Rao, G. V. Subba Rao and S. Ramdas, $J$. Phys. Chem. 73 (1969) 672.

[6] T. Takahashi, H. Iwahara and Y. Nagai, J. Appl. Electrochem. 2 (1972) 97.

[7] G. Gattow und D. Schütze, Z. Anorg. Allg. Chem. 328 (1964) 44.

[8] R. Matsuzaki, H. Masumizu and Y. Saeki, Bull. Chem. Soc. Japan 48 (11) (1975) 3397.

[9] L. G. Sillén, Arkiv Kemi 12A (18) (1937) 1.

[10] Idem, Krist A103 (1941) 274

[11] G. Malmros, Acta. Chem. Scand. 24 (1970) 384.

[12] T. Takahashi and H. Iwahara, J. Appl. Electrochem. 3 (1973) 65.

[13] T. Takahashi, H. Iwahara and T. Arao, Ibid 5 (1975) 187.

[14] T. Takahashi, T. Esaka and H. Iwahara, Ibid 7 (1977) 299.

[15] Idem, ibid 7(1977) 303.

[16] Idem, ibid 5 (1975) 197.

[17] Idem, J. Solid State Chem. 16 (1976) 317.

[18] Idem, J. Appl. Electrochem. 7 (1977) 31.

[19] Idem, J. Electrochem. Soc. 124 (1977) 1563.

[20] K. W. Browall, Electrochem. Soc. Spring Meeting abstract 467 (1978).

[21] L. Heyne, in 'Measurement of Oxygen' (edited by H. Degn et al.) Elsevier, Amsterdam, Oxford, N.Y. (1976).

[22] R. K. Datta and J. P. Meehan, Z. Anorg. Allg. Chem. 383 (1971) 328.

[23] S. N. Nasonova, V. V. Serebrennikov and G. A. Narnov, Russ. J. Inorg. Chem. 18 (1973) 1244.

[24] H. Kruidhof, Anal. Chimica Acta 99 (1978) 193.

[25] T. v. Dijk, K. J. de Vries and A. J. Burggraaf, 
submitted to Phys. St. Sol. (A).

[26] J. E. Bauerle and J. Hrizo, J. Phys. Chem. Solids 30 (1969) 565.

[27] R. E. W. Casselton, Phys. St. Sol. (A) 2 (1970) 571.

[28] R. Guillermo, P. Conflant, J. C. Boivin and D.
Thomas, Rev. Chim. min. 15 (1978) 153.

[29] P. Conflant, J. C. Boivin, and D. Thomas, J. Solid State Chem. 18 (1976) 133

[30] A. I. Ioffe, D. S. Rutman and S. V. Karpachov, Electrochim. Acta 23 (1978) 141. 